\title{
PENGEMBANGAN PERANGKAT PEMBELAJARAN INKUIRI TERBIMBING BERBASIS AKTIVITAS HIGHER ORDER THINKING PADA KELAS V SEKOLAH DASAR
}

\author{
I Dewa Gede Putra Widiarta ${ }^{1}$, Desak Putu Parmiti ${ }^{2}$, dan I Gede Margunayasa ${ }^{3}$ \\ 1,2,3 Prodi Pendidikan Guru Sekolah Dasar, FIP Universitas Pendidikan Ganesha \\ Email: dewapoetra15@gmail.com
}

\begin{tabular}{l}
\hline Info Artikel \\
\hline Sejarah Artikel: \\
Diserahkan 12 Juli 2019 \\
Direvisi 17 Oktober 2019 \\
Disetujui 18 November 2019 \\
\hline
\end{tabular}

Keywords:

guided inquiry, learning device, higher order thinking.

\section{Abstract}

This study aims to develop a guided inquiry learning tool based on higher order thinking (HOT) activities on the theme of 9th subtheme 1 grade V elementary school.

This research is a development research conducted using the ADDIE model with stages, namely (1) analyze, (2) design, (3) development, (4) implementation, and ( 5) evaluation. However, the implementation phase and the evaluation stage were not carried out due to time constraints. The subject of this research is the learning kit consisting of syllabus, lesson plans, and LKPD. The instrument used to measure the validity of the device is the learning device assessment sheet to the expert. The device validation data that has been collected is then analyzed using the mean formula to find out the average score of device validity.

The results of data analysis show that: (1) the average syllabus validation score is 4.73 , is in very good qualifications, the average RPP validation score is 4.75 , is in a very good qualification, the average LKPD validation score is 4.86, are in very good qualifications, and (2) the acquisition of the results of the validity of the equipment (syllabus, RPP, and $L K P D)$ shows that the equipment that has been developed has very good qualifications.

\footnotetext{
Abstrak

Penelitian ini bertujuan untuk mengembangkan perangkat pembelajaran inkuiri terbimbing berbasis aktivitas higher order thinking (HOT) pada tema 9 subtema 1 kelas V sekolah dasar.

Penelitian ini merupakan penelitian pengembangan yang dilaksanakan menggunakan model ADDIE dengan tahapan-tahapan, yaitu (1) analyze (analisis), (2) design (perancangan), (3) development (pengembangan), (4) implementation (implementasi), dan (5) evaluation (evaluasi). Namun tahap implementasi dan tahap evaluasi tidak dilaksanakan karena keterbatasan waktu. Subjek penelitian ini yaitu perangkat pembelajaran yang terdiri atas silabus, RPP, dan LKPD. Instrumen yang digunakan untuk mengukur validitas perangkat yakni lembar penilaian perangkat pembelajaran pada ahli. Data validasi perangkat yang telah dikumpulkan kemudian dianalisis dengan menggunakan rumus mean untuk mengetahui rata-rata skor validitas perangkat.

Hasil analisis data menunjukkan bahwa: (1) rata-rata skor validasi silabus yaitu 4,73, berada pada kualifikasi sangat baik, rata-rata skor validasi RPP yaitu 4,75, berada pada kualifikasi sangat baik, rata-rata skor validasi LKPD yaitu 4,86, berada pada kualifikasi sangat baik, dan (2) perolehan hasil validitas perangkat (silabus, RPP, dan LKPD) menunjukkan bahwa perangkat yang telah dikembangkan memiliki kualifikasi sangat baik.
}

(C) 2019 Universitas Muria Kudus 
I Dewa Gede Putra Widiarta, Desak Putu Parmiti, dan I Gede Margunayasa

PENGEMBANGAN PERANGKAT PEMBELAJARAN INKUIRI TERBIMBING BERBASIS ... REFLEKSI EDUKATIKA : Jurnal Ilmiah Kependidikan 10 (1) Desember 2019. Hlm. 29-39

\section{PENDAHULUAN}

Perkembangan ilmu pengetahuan dan teknologi yang semakin pesat menuntut adanya sumber daya manusia (SDM) yang berkualitas. SDM yang berkualitas dihasilkan melalui pendidikan yang berkualitas pula. Kualitas pendidikan harus ditingkatkan untuk menghasilkan SDM yang menguasai ilmu pengetahuan dan teknologi sehingga mampu bersaing pada era revolusi industri 4.0. Era revolusi industri 4.0 menuntut SDM yang menguasai elemen 4C yaitu critical thinking dan problem solving, communication, collaboration, dan creativity seperti yang digarisbawahi Forum Ekonomi Dunia (WEF) (Ilias \& Ladin, 2018). SDM yang menguasai elemen 4C dihasilkan melalui pembelajaran yang berkualitas.

Pembelajaran yang berkualitas adalah pembelajaran yang tepat sasaran sesuai dengan standar kompetensi lulusan. Sasaran tersebut mencakup pengembangan ranah sikap, pengetahuan, dan keterampilan yang dielaborasikan dalam proses pembelajaran (Kemendikbud, 2016). Ketiga ranah tersebut dapat dikembangkan melalui berbagai aktivitas pembelajaran yang dirancang dengan menggunakan pendekatan ilmiah. Pembelajaran menggunakan pendekatan ilmiah (scientific) lebih efektif apabila diperkuat dengan pembelajaran inkuiri (inquiry learning). Untuk mengembangkan ranah kognitif, afektif, dan kognitif siswa, perlu dirancang sebuah perangkat pembelajaran inkuiri (inquiry learning) yang menekankan penguasaan elemen 4C (Critical Thinking dan Problem Solving, Communication, Collaboration, Creativity). Critical thinking dan problem solving merupakan bagian dari HOT (Higher Order Thinking) yang merupakan salah satu keterampilan abad 21 (Ramli, 2015).

Kenyataan di SD Gugus XIII Kecamatan Buleleng, berdasarkan hasil analisis yang telah dilaksanakan, perangkat pembelajaran yang digunakan belum sesuai dengan Permendikbud No. 22 Tahun 2016. Berdasarkan analisis perangkat pembelajaran yang dilaksanakan oleh peneliti, didapatkan hasil yaitu (1) komponen pembelajaran pada silabus belum menunjukkan aktivitas HOT dan kegiatan inkuiri dengan jelas, (2) sumber belajar pada silabus tidak sesuai dengan materi pokok, (3) sistematika komponenkomponen rencana pelaksanaan pembelajaran (RPP) yang digunakan belum sesuai dengan Permendikbud No. 22 Tahun 2016, (4) indikator pembelajaran yang dibuat masih bersifat umum seperti kompetensi dasar (KD) belum dibuat secara spesifik untuk menunjukkan pengembangan HOT, (5) langkah-langkah pembelajaran di RPP belum memperlihatkan aktivitas HOT, (6) kegiatan pembelajaran belum memberikan ruang yang cukup kepada siswa untuk aktif menunjukkan kreativitas, prakarsa, dan kemandirian sesuai dengan minat dan bakatnya, serta perkembangan fisik atau psikologis, (7) instrumen penilaian yang digunakan belum mengukur ketercapaian indikator HOT, dan (8) guru belum memiliki lembar kerja peserta didik (LKPD) untuk digunakan dalam proses pembelajaran. Perangkat pembelajaran pada kenyataannya belum sesuai dengan harapan pemerintah dalam upaya peningkatan kualitas pendidikan. Berdasarkan wawancara dengan guru, RPP yang digunakan merupakan hasil kelompok kerja guru (KKG) yang telah dilaksanakan sehingga komponenkomponen RPP yang digunakan di Gugus XIII Kecamatan Buleleng sama di semua SD.

Berdasarkan permasalahan di atas perlu adanya pengembangan perangkat pembelajaran yang mampu melibatkan siswa melakukan aktivitas HOT dalam proses pembelajaran. Pengembangan perangkat pembelajaran merupakan upaya yang dilaksanakan untuk memperbaiki kekurangan pada perangkat pembelajaran sehingga bisa menjadi lebih baik untuk digunakan. Perangkat pembelajaran merupakan segala alat dan bahan yang digunakan guru untuk melakukan proses pembelajaran. Bahan ajar adalah bahan yang digunakan guru untuk membantu melaksanakan kegiatan pembelajaran (Gunada, Sahidu, dan Sutrio, 2015). Perangkat pembelajaran merupakan sekumpulan sumber belajar yang digunakan guru dalam melakukan kegiatan pembelajaran (Tanjung dan Nababan, 2018). Perangkat pembelajaran adalah alat yang digunakan guru dalam melaksanakan proses pembelajaran sehingga tercipta interaksi antara guru dan siswa (Anugraheni, 2018). Berdasarkan beberapa pendapat tersebut dapat disimpulkan bahwa perangkat pembelajaran merupakan alat dan bahan yang menjadi sumber belajar yang digunakan guru dalam proses pembelajaran. Perangkat pembelajaran seperti silabus, rencana pelaksanaan pembelajran (RPP), dan lembar kerja peserta didik (LKPD) perlu dirancang dengan kegiatan-kegiatan pembelajaran yang mampu meningkatkan kemampuan HOT siswa.

Silabus merupakan acuan dalam menyusun kerangka pembelajaran yang mencakup kompetensi inti/standar kompetensi, kompetensi dasar, materi pembelajaran, kegiatan pembelajaran, indikator pencapaian kompetensi 
I Dewa Gede Putra Widiarta, Desak Putu Parmiti, dan I Gede Margunayasa

PENGEMBANGAN PERANGKAT PEMBELAJARAN INKUIRI TERBIMBING BERBASIS ...

REFLEKSI EDUKATIKA : Jurnal Ilmiah Kependidikan 10 (1) Desember 2019. Hlm. 29-39

untuk penilaian, penilaian, alokasi waktu, dan sumber belajar pada mata pelajaran atau tema (Kemendikbud, 2016). Rencana pelaksanaan pembelajaran merupakan langkah-langkah pembelajaran dalam sekali tatap muka atau lebih yang dirancang berdasarkan silabus yang digunakan (Kemendikbud, 2016). LKPD adalah bahan ajar cetak yang berisi petunjuk serta langkah-langkah kegiatan untuk menyelesaikan suatu permasalahan (Istikharah dan Zulkifli, 2017). LKPD bisa dibuat dan digunakan untuk semua mata pelajaran disesuaikan dengan materi pelajaran yang disampaikan

Peningkatan kemampuan HOT siswa bisa dilaksanakan melalui pembelajaran berbasis inkuiri dengan disertai aktivitas HOT. Pembelajaran inkuiri sangat penting sebagai sebuah strategi pendidikan bagi individu yang melek ilmiah. Inkuiri memiliki kesamaan makna dengan proses sains, penyelidikan ilmiah didasarkan pada keterampilan bertanya, pengamatan, menginterogasi, merujuk, mengukur, mengklasifikasikan, memperkirakan, menafsirkan, dan menganalisis data. Although have a similar meaning with science processes, scientific inquiry is based on skills such as wondering, questioning observing, interrogating, referring, classifying, predicting, measuring, interpreting, and analyzing data (Kizilaslan, Sozbilir, dan Yasar, 2012). Inkuiri merupakan model pembelajaran yang populer, inkuiri berasal dari kata to inquire yang artinya ikut serta mengajukan pertanyaan, mencari informasi, dan melakukan penyelidikan untuk mencari solusi terhadap suatu permasalahan (Fathurrohman, 2015). Jadi pembelajaran inkuiri merupakan pembelajaran dengan melibatkan kemampuan intelektual siswa secara maksimal dalam menyelesaikan suatu permasalahan melalui aktivitas berpikir secara sistematis, kritis, logis, dan analitis.

Model pembelajaran inkuiri memiliki beberapa keuntungan, yaitu 1) mengubah pola pembelajaran dari penyajian informasi menjadi mencari dan mengolah data untuk memecahkan sebuah permasalahan, 2) siswa diberikan ruang untuk belajar menggunakan gaya belajarnya guru berperan sebagai fasilitator, 3) model pembelajaran inkuiri terbimbing mampu mengembangkan konsep diri siswa, 4) siswa belajar dengan mengumpulkan informasi atau data dari berbagai sumber bukan hanya dari guru, dan 5) mampu mengurangi kebiasaan menghafal dalam belajar (Simbolon \& Sahyar, 2015). Model pembelajaran inkuiri terbimbing memiliki beberapa keuntungan, yaitu 1) menekankan pengembangan aspek kognitif, afektif, dan psikomotorik secara seimbang, 2) memberi ruang kepada siswa untuk belajar dengan cara celajarnya, dan 3) sesuai dengan perkembangan psikologi belajar modern yaitu belajar adalah perubahan tingkah laku melalui adanya pengalaman yang didapatkan (Khamdun, 2014)

Terdapat 3 model pembelajaran inkuiri yaitu model inkuiri terbimbing (guided inquiry), model inkuiri bebas (free inquiry), model inkuiri yang bebas dimodifikasi (modified free inquiry) (Sari, Wiyasa, \& Ganing, 2018). Pembelajaran inkuiri terbimbing merupakan model pembelajaran yang melibatkan siswa untuk berpikir secara aktif dalam membangun pengetahuannya sendiri dengan bimbingan guru pada proses pembelajaran. Pembelajaran inkuiri terbimbing dalam penerapannya, aktivitas siswa dibantu oleh guru dengan menyediakan bimbingan dan petunjuk yang cukup luas untuk menyelesaikan suatu permasalahan (Fathurrohman, 2015). Terdapat enam fase kegiatan dalam pembelajaran inkuiri terbimbing, yaitu 1) orientasi, 2) merumuskan masalah, 3) membuat hipotesis, 4) mengumpulkan data, 5) menguji hipotesis, dan 6) membuat kesimpulan (Sanjaya, 2016). Prosedur kegiatan inkuiri terbimbing dilakukan dengan melibatkan siswa menemukan cara untuk memecahkan masalah yang dihadapi melalui percobaan (Retno \& Marlina, 2018). Pembelajaran dengan mengikuti prosedur tersebut mampu mengembangkan kemampuan HOT siswa dalam menyelesaikan suatu permasalahan dibantu oleh guru sebagai fasilitator dalam proses pembelajaran. Proses penemuan melalui aktivitas siswa sangat ditekankan pada model pembelajaran inkuiri terbimbing. Guided inquiry stresses the importance of discovery process by the students themselves (Margunayasa, et al., 2019). Pembelajaran inkuiri terbimbing lebih efektif apabila disertai dengan aktivitas HOT.

HOT merupakan suatu proses berpikir secara kompleks dalam memanipulasi data yang didapatkan sebagai pemahaman baru yang teruji kebenarannya (Wahyuni, 2017). HOT merupakan suatu proses berpikir yang dilakukan dengan menghubungkan, memanipulasi, dan mentransformasi informasi secara kritis dan kreatif untuk memecahkan suatu permasalahan (Rofiah, Aminah, dan Ekawati, 2013). HOT meliputi kemampuan berpikir kritis dan kemampuan berpikir kreatif (Lailly dan Wisudawati, 2015). Berdasarkan beberapa pandangan tersebut dapat disimpulkan bahwa aktivitas HOT adalah proses berpikir secara kritis 
dan kreatif yang terjadi secara kompleks dalam diri seseorang untuk mengintrepretasikan, menganalisa, dan memanipulasi informasi guna mengetahui kebenaran sebuah informasi dalam memecahkan masalah.

Pembelajaran dengan aktivitas HOT perlu dikembangkan dalam pemecahan masalah, dengan aktivitas HOT siswa berpikir kreatif dan kritis terhadap suatu permasalahan untuk mencari solusi yang tepat dan rasional sehingga masalah yang dihadapi bisa terpecahkan. Aktivitas HOT melatih kemampuan siswa dalam menganalisis gagasan atau ide, merancang sebuah hipotesis, mengkonstruksi informasi yang didapatkan dengan memberikan penjelasanpenjelasan terhadap informasi tersebut guna memecahkan suatu permasalahan, dan memahami informasi yang kompleks dengan jelas (Widodo dan Kadarwati, 2013). Aktivitas HOT meningkatkan keaktifan siswa dalam membangun pengetahuannya sendiri melalui pengalaman yang didapatkan. Pembelajaran menjadi bermakna apabila mampu melibatkan siswa secara aktif membangun pengetahuannya melalui aktivitas HOT. Pengetahuan yang diperoleh berdasarkan pengalaman yang didapatkan oleh siswa setelah melakukan proses pembelajaran bertahan lebih lama dalam ingatan siswa.

Pembelajaran inkuiri terbimbing berbasis aktivitas HOT melatih siswa untuk berpikir kritis dan berpikir kreatif dalam menyelesaikan suatu permasalahan melalui kegiatan percobaan yang dilaksanakan dalam proses pembelajaran di kelas maupun di luar kelas. Pengalaman yang didapatkan siswa melalui kegiatan percobaan yang telah dilaksanakan menjadi pemahaman dan pengetahuan baru yang dihasilkan melalui proses mental siswa secara individual. Pengetahuan yang didapatkan melalui proses mental yang dialami siswa melalui kegiatan inkuiri dengan melibatkan aktivitas HOT bertahan lama dalam ingatan siswa dibandingan pengetahuan yang didapatkan dengan cara menghafal materi. Hal ini dapat dicapai melalui pengembangan perangkat pembelajaran inkuiri terbimbing berbasis aktivitas HOT.

Adapun tujuan yang ingin dicapai dalam penelitian ini adalah mengembangkan perangkat pembelajaran inkuiri terbimbing berbasis aktivitas higher order thinking (HOT) pada Tema 9 Subtema 1 kelas V SD.

\section{METODE PENELITIAN}

Penelitian ini merupakan penelitian pengembangan perangkat pembelajaran inkuiri terbimbing berbasis aktivitas HOT yang terdiri atas silabus, RPP, dan LKPD. Penelitian ini menggunakan model pengembangan yaitu model ADDIE (Analyze, Design, Development, Implementation, Evaluation) yang merupakan model desain instruksional yang dikembangkan oleh Reiser dan Mollenda (Hananta dan Sukardi, 2018). Model ADDIE merupakan model yang sifatnya umum, bisa digunakan dalam mengembangkan produk-produk untuk mengatasi permasalahan dalam dunia pendidikan dan sesuai untuk peneilitan pengembangan (Santosa, Santyadiputra, dan Divayana, 2017). Pemilihan model ADDIE didasari pertimbangan bahwa model ADDIE memiliki alur proses pengembangan perangkat pembelajaran yang sistematis dan jelas sehingga model ini dipilih untuk digunakan dalam penelitian ini.

Prosedur pengembangan perangkat pembelajaran inkuiri terbimbing berbasis aktivitas HOT berupa silabus, RPP, dan LKPD dilaksanakan melalui beberapa tahap. Tahaptahap yang dilaksanakan yaitu analisis (analyze), perancangan (design), pengembangan (development), implementasi (implementation) dan evaluasi (evaluation), namun tahap implementasi dan evaluasi tidak dilaksanakan karena keterbatasan waktu.

Setelah perangkat selesai dikembangkan selanjutnya dilaksanakan uji coba produk untuk mengetahui validitas perangkat pembelajaran inkuiri terbimbing berbasis aktivitas HOT yang telah dikembangkan. Desain uji coba yang dilaksanakan dalam penelitian ini adalah melalui tahap review oleh ahli pembelajaran untuk mengetahui validitas perangkat pembelajaran yang telah dikembangkan. Setelah perangkat pembelajaran di-review oleh ahli pembelajaran, data yang diperoleh kemudian dianalisis dan dilaksanakan revisi pada perangkat pembelajaran berdasarkan data hasil review tersebut.

Subjek uji coba produk adalah tempat di mana data untuk variabel penelitian diperoleh. Subjek penelitian ini adalah perangkat pembelajaran yang terdiri atas satu silabus, enam RPP, dan enam LKPD. Perangkat pembelajaran sebagai subjek penelitian diuji kepada ahli pembelajaran untuk mengetahui kelayakan perangkat pembelajaran yang telah dikembangkan. Objek pada penelitian ini adalah validitas perangkat pembelajaran yang terdiri atas satu silabus, enam rencana pelaksanaan pembelajaran (RPP), dan enam lembar kerja peserta didik (LKPD).

Data yang diperoleh dalam penelitian ini dikelompokkan menjadi dua, yaitu data kualitatif 
I Dewa Gede Putra Widiarta, Desak Putu Parmiti, dan I Gede Margunayasa

PENGEMBANGAN PERANGKAT PEMBELAJARAN INKUIRI TERBIMBING BERBASIS ...

REFLEKSI EDUKATIKA : Jurnal Ilmiah Kependidikan 10 (1) Desember 2019. Hlm. 29-39

dan data kuantitatif. Data kualitatif adalah data yang disajikan dalam bentuk kata-kata berupa masukan, tanggapan, kritik, dan saran yang diperoleh dari tahap review oleh ahli pembelajaran. Data kuantitatif adalah data berupa skor yang diperoleh dari lembar penilaian perangkat pembelajaran (silabus, RPP, dan LKPD) yang diisi oleh ahli pembelajaran.

Metode pengumpulan data dalam penelitian pengembangan perangkat pembelajaran ini adalah metode kuesioner. Instrumen yang digunakan dalam penelitian ini adalah rating scale berupa lembar penilaian perangkat. Instrumen yang digunakan harus valid sebelum diuji dalam penelitian. Untuk menguji validitas isi instrumen adalah melalui penilaian pakar (judges) atau panel pakar dalam bidangnya. Uji validitas isi dilaksanakan menggunakan rumus Gregory. Hasil uji validitas isi menunjukkan koefisien validitas isi instrumen penilaian slabus $=1,00$, instrumen penilaian RPP $=1,00$, dan instrumen penilaian LKPD $=1,00$. Hasil uji validitas isi instrumen penilaian silabus, RPP, dan LKPD apabila diklasifikasikan berdasarkan kriteria koefisien validitas isi, berada pada rentangan $0,80-1,00$ atau validitas isi sangat tinggi.

Metode dan teknik analisis data yang digunakan dalam penelitian pengembangan ini adalah teknik analisis statistik deskriptif kualitatif dan analisis statistik deskriptif kuantitatif. Metode analisis statistik deskriptif kualitatif digunakan untuk mengolah data berupa masukan, tanggapan, kritik, dan saran hasil review ahli pembelajaran, terhadap perangkat pembelajaran yang dikembangkan melalui pemberian lembar penilaian perangkat pembelajaran. Hasil review dari ahli pembelajaran kemudian dianalisis dengan mengelompokkan data kualitatif berupa masukan, tanggapan, kritik, dan saran tersebut. Hasil analisis kemudian digunakan untuk memperbaiki perangkat pembelajaran yang dikembangkan.

Metode analisis statistik kuantitatif digunakan untuk mendeskripsikan rata-rata skor dari masing-masing ahli pembelajaran terkait perangkat pembelajaran yang dikembangkan. Metode analisis statistik deskriptif kuantitatif digunakan untuk menganalisis data berupa skor yang didapatkan melalui pemberian lembar penilaian perangkat pembelajaran kepada guru dan dosen sebagai ahli pembelajaran. Skor yang diperoleh dari masing-masing indikator penilaian kemudian dihitung rata-ratanya untuk mengetahui validitas perangkat, dengan menggunakan rumus mean. Rata-rata skor yang diperoleh kemudian dikonversikan dengan menggunakan pedoman konversi skala lima untuk mengetahui validitas masing-masing komponen perangkat maupun keseluruhan perangkat yang dikembangkan (silabus, RPP, LKPD). Indikator keberhasilan penelitian ini adalah rata-rata skor validasi perangkat pembelajaran minimal pada kategori baik dengan rentang $3,33<\mathrm{X} \leq 4,01$.

\section{HASIL DAN PEMBAHASAN \\ Hasil}

Analisis kebutuhan dilaksanakan peneliti dengan menganalisis perangkat pembelajaran yang digunakan di Gugus XIII Kecamatan Buleleng pada Tema 9 Subtema 1 kelas V SD. Hasil analisis kebutuhan menunjukkan bahwa perangkat pembelajaran berupa silabus dan RPP yang digunakan di SD di Gugus XIII Kecamatan Buleleng belum sesuai dengan Permendikbud No. 22 Tahun 2016 dan kurang mengembangkan kemampuan HOT siswa. Perangkat pembelajaran seperti LKPD juga belum tersedia di sekolah.

Hasil analisis karakteristik siswa yaitu siswa SD di Gugus XIII Kecamatan Buleleng masih berada pada tahap operasional konkret. Siswa kelas V di Gugus XIII Kecamatan Buleleng pada umumnya berusia 11 tahun. Pembelajaran untuk siswa dengan usia 11 tahun hendaknya dilaksanakan dengan memberikan contoh-contoh yang nyata kepada siswa.

Analisis kurikulum dilaksanakan untuk menentukan materi yang dimuat dalam perangkat pembelajaran yang dirancang. Penentuan ini dilaksanakan berdasarkan Permendikbud No. 24 Tahun 2016 tentang kompetensi inti dan kompetensi dasar serta buku guru kelas V Tema 9 Benda-Benda di Sekitar Kita edisi revisi 2017. Materi pokok yang dianalisis khususnya untuk kelas V pada Subtema 1 Benda Tunggal dan Campuran. Hasil analisis kurikulum berupa kompetensi dasar yang dijabarkan menjadi beberapa indikator dijadikan sebagai acuan dalam menyusun perangkat pembelajaran seperti silabus, RPP, dan LKPD inkuiri terbimbing berbasis aktivitas HOT.

Setelah dilaksanakan tahap analisis kemudian dilanjutkan tahap perencanaan perangkat pembelajaran yang dibuat. Perangkat pembelajaran yang dibuat pada penelitian ini berupa silabus, RPP, dan LKPD. Silabus dibuat dengan komponen-komponen, yaitu 1) identitas sekolah yang meliputi satuan pendidikan dan kelas, 2) kompetensi inti yang menggambarkan kompetensi aspek sikap, pengetahuan, dan 
I Dewa Gede Putra Widiarta, Desak Putu Parmiti, dan I Gede Margunayasa

PENGEMBANGAN PERANGKAT PEMBELAJARAN INKUIRI TERBIMBING BERBASIS ...

REFLEKSI EDUKATIKA : Jurnal Ilmiah Kependidikan 10 (1) Desember 2019. Hlm. 29-39

keterampilan yang dipelajari peserta didik di sekolah dasar, 3) kompetensi dasar berdasarkan Permendikbud No. 24 tahun 2016, 4) tema yang disesuaikan dengan kelas, 5) materi pokok sesuai dengan kompetensi dasar, 6) pembelajaran dengan mengikuti langkah-langkah pembelajaran inkuiri terbimbing dan mampu mengembangkan kemampuan HOT, 7) penilaian yang mampu mengukur kemampuan HOT, 8) alokasi waktu yang disesuaikan dengan materi pokok, dan 9) sumber belajar yang sesuai dengan materi pokok. RPP dirancang dengan komponenkomponen, yaitu 1) identitas sekolah yaitu nama satuan pendidikan, 2) identitas mata pelajaran atau tema/subtema, 3) kelas/semester, 4) materi pokok sesuai dengan kompetensi dasar, 5) alokasi waktu ditentukan sesuai dengan keperluan untuk pencapaian kompetensi dasar dan materi pokok, 6) tujuan pembelajaran yang dirumuskan berdasarkan indikator pencapaian kompetensi, 7) kompetensi dasar dan indikator pencapaian kompetensi, 8) materi pembelajaran, memuat fakta, konsep, prinsip, dan prosedur yang relevan dengan kompetensi dasar, 9) metode pembelajaran yang disesuaikan dengan karakteristik peserta didik dan menggunakan pembelajaran inkuiri terbimbing, 10) media pembelajaran yang relevan dengan materi pokok, 11) sumber belajar yang relevan dengan materi pokok, 12) langkah-langkah pembelajaran dilaksanakan melalui tahapan pendahuluan, inti, dan penutup dengan mengikuti langkah-langkah pembelajaran inkuiri terbimbing yang mencerminkan pencapaian kemampuan HOT, dan 13) penilaian hasil belajar yang mampu mengukur kemampuan HOT.

LKPD dirancang dengan komponenkomponen, yaitu 1) sampul LKPD dirancang yang terdiri atas judul, gambar, kelas, semester, nama anggota kelompok, tanggal kegiatan, tema, subtema, dan materi pokok. Gambar yang terdapat dalam sampul disesuaikan dengan materi pokok, 2) tujuan sesuai dengan RPP, 3) petunjuk kerja LKPD untuk mengarahkan siswa dalam melakukan kegiatan LKPD, 4) kegiatan siswa dirancang sebagai sarana diskusi siswa serta sesuai dengan tujuan pembelajaran untuk mengembangkan kemampuan HOT, dan 5) Kesimpulan dirancang untuk menyediakan tempat menuliskan kesimpulan yang diperoleh berdasarkan jawaban atas pertanyaan yang diberikan sebelumnya.

Perangkat pembelajaran yang dikembangkan mengakomodasi kompetensi inti (KI), kompetensi dasar (KD), indikator pencapaian kompetensi dan tujuan pembelajaran yang telah dijabarkan dan diprogramkan mengikuti model pembelajaran inkuiri terbimbing berbasis aktivitas HOT. Setiap komponen perangkat pembelajaran berbeda untuk setiap unit pembelajaran dalam setiap tahapan/fase inkuiri terbimbing, yakni silabus memuat komponen-komponen yang digunakan untuk merancang RPP, RPP memuat rencana pelaksanaan pembelajaran, dan LKPD berisikan tagihan kegiatan terhadap siswa. RPP dan LKPD dikembangkan mengikuti langkah-langkah kegiatan inkuiri terbimbing dengan aktivitas HOT.

Setelah perangkat selesai dikembangkan dilaksanakan uji coba produk melalui tahap review ahli untuk mengetahui validitas perangkat. Berdasarkan analisis validitas silabus yang telah dilaksanakan diketahui bahwa masing-masing komponen silabus mendapatkan rata-rata skor validasi dengan rentang skor $4,01<\mathrm{X} \leq 5,01$ berdasarkan pedoman konversi skala lima, masing-masing komponen memiliki kualifikasi sangat baik. Rata-rata skor validasi silabus secara keseluruhan adalah 4,73. Rata-rata skor validasi silabus apabila dikonversikan dengan pedoman konversi skala lima termasuk dalam rentang skor $4,01<\mathrm{X} \leq 5,01$ dengan kualifikasi sangat baik. Hal tersebut menunjukkan bahwa validitas silabus secara keseluruhan memiliki kualifikasi sangat baik. Hasil analisis validasi RPP berupa rata-rata skor validasi dan kualifikasi RPP dapat dilihat pada Gambar 1.

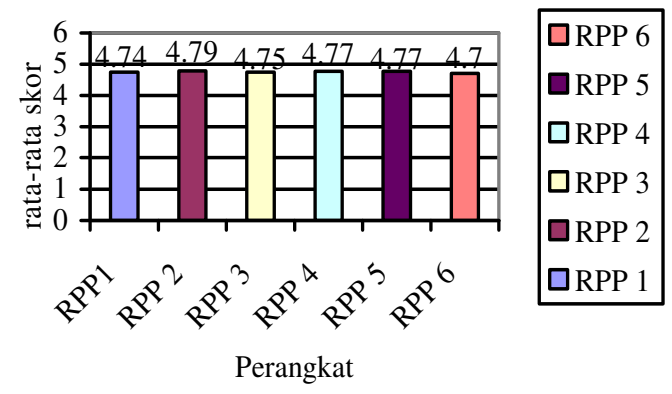

Gambar 1. Diagram rata-rata skor validasi RPP

Berdasarkan Gambar 1, diketahui bahwa masing-masing RPP mendapatkan rata-rata skor validasi yaitu RPP $1=4,74$, RPP $2=4,79$, RPP 3 $=4,75$, RPP $4=4,77$, RPP $5=4,77$, dan RPP $6=$ 4,7. Rata-rata skor validasi masing-masing RPP apabila dikonversikan dengan pedoman konversi skala lima berada pada rentang skor $4,01<\mathrm{X} \leq 5,01$, sehingga masing-masing RPP memiliki kualifikasi sangat baik. Masing-masing komponen pada RPP sebagian besar 
I Dewa Gede Putra Widiarta, Desak Putu Parmiti, dan I Gede Margunayasa

PENGEMBANGAN PERANGKAT PEMBELAJARAN INKUIRI TERBIMBING BERBASIS ...

REFLEKSI EDUKATIKA : Jurnal Ilmiah Kependidikan 10 (1) Desember 2019. Hlm. 29-39

mendapatkan rata-rata skor validasi pada rentang skor $4,01<\mathrm{X} \leq 5,01$ dengan kualifikasi sangat baik, namun Komponen 7 pada RPP 3 mendapatkan rata-rata skor validasi pada rentang skor $3,33<\mathrm{X} \leq 4,01$ dengan kualifikasi baik, karena pada Komponen 7 pada RPP 3 kompetensi dasar belum sesuai dengan silabus sehingga perlu dilaksanakan revisi terhadap komponen tersebut. Secara keseluruhan rata-rata skor validitas RPP adalah 4,75. Secara keseluruhan rata-rata skor validitas RPP adalah 4,75. Rata-rata skor validitas RPP apabila dikonversikan dengan pedoman konversi skala lima berada pada rentang skor $4,01<\mathrm{X} \leq 5,01$ dengan kualifikasi sangat baik. Hal tersebut menunjukkan bahwa validitas RPP secara keseluruhan memiliki kualifikasi sangat baik. Hasil analisis validasi LKPD berupa rata-rata skor validasi dan kualifikasi LKPD dapat dilihat pada Gambar 2.

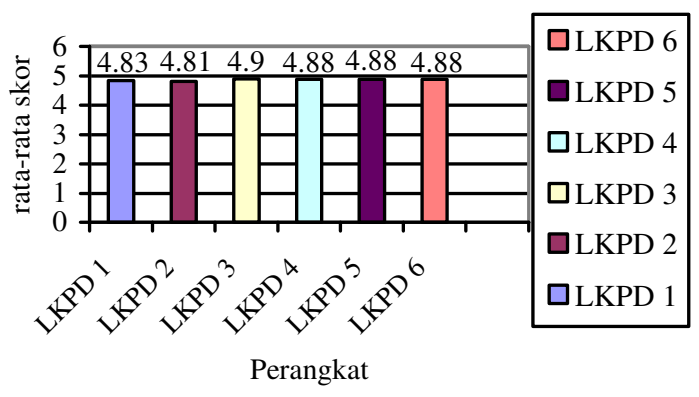

Gambar 2. Diagram rata-rata skor validasi LKPD

Berdasarkan Gambar 2, diketahui bahwa masing-masing LKPD mendapatkan rata-rata skor validasi yaitu LKPD $1=4,83$, LKPD $2=$ 4,81 , LKPD $3=4,90$, LKPD $4=4,88$, LKPD $5=$ 4,88 , dan LKPD $6=4,88$. Rata-rata skor validasi masing-masing LKPD apabila dikonversikan dengan pedoman konversi skala lima berada pada rentang skor $4,01<\mathrm{X} \leq 5,01$, sehingga masing-masing LKPD memiliki kualifikasi sangat baik. Masing-masing komponen pada LKPD sebagian besar mendapatkan rata-rata skor validasi pada rentang skor $4,01<\mathrm{X} \leq 5,01$ dengan kualifikasi sangat baik, namun Komponen 3 pada semua LKPD mendapatkan rata-rata skor validasi pada rentang skor $3,33<\mathrm{X} \leq 4,01$ dengan kualifikasi baik, karena pada Komponen 3 pada semua LKPD tujuan belum sesuai dengan RPP dan belum menunjukkan HOT sehingga perlu dilaksanakan revisi terhadap komponen tersebut. Secara keseluruhan rata-rata skor validitas LKPD adalah 4,86. Rata-rata skor validitas LKPD apabila dikonversikan dengan pedoman konversi skala lima berada pada rentang skor $4,01<\mathrm{X} \leq 5,01$ dengan kualifikasi sangat baik. Hal tersebut menunjukkan bahwa validitas LKPD secara keseluruhan memiliki kualifikasi sangat baik.

\section{Pembahasan}

Pengembangan perangkat pembelajaran inkuiri terbimbing berbasis aktivitas HOT yang dihasilkan meliputi silabus, RPP, dan LKPD. Pengembangan perangkat pembelajaran diawali dengan tahap analisis yang terdiri atas analisis kebutuhan, analisis, karakteristik siswa, dan analisis kurikulum. Setelah dilaksanakan analisis, dilanjutkan dengan tahap perancangan.

Analisis kebutuhan yang telah dilaksanakan peneliti pada perangkat pembelajaran yang digunakan di Gugus XIII Kecamatan Buleleng pada Tema 9 Subtema 1 kelas V SD belum menunjukkan pengembangan kemampuan HOT dan pembelajaran inkuiri yang mendukung pendekatan saintifik sesuai dengan Permendikbud No. 22 Tahun 2016. Perangkat pembelajaran seperti LKPD belum tersedia untuk membantu guru dalam memberikan pembelajaran kepada siswa. Penggunakan LKPD memudahkan siswa dalam belajar mandiri dengan mengikuti petunjuk yang sudah tersedia di dalamnya dan memudahkan guru dalam membimbing siswa dalam proses pembelajaran. Belum tersedianya LKPD membuat guru hanya menggunakan media lain yang tersedia di sekolah. Penggunaan LKPD mampu memfasilitasi siswa untuk aktif dalam proses pembelajaran dan mengembangkan kemampuan HOT, karena siswa diberikan kesempatan untuk membangun pengetahuannya sendiri melalui kegiatan yang dilaksanakan.

Selain belum tersedianya LKPD, silabus dan RPP yang digunakan guru juga hanya mengandalkan silabus dan RPP yang didapatkan melalui KKG sehingga banyak komponenkomponennya yang belum lengkap dan kurang sesuai. Kegiatan pembelajaran dalam silabus dan RPP belum banyak menunjukkan pengembangan kemampuan HOT siswa. Untuk itu, diperlukan perangkat pembelajaran yang mampu membimbing siswa untuk mengkonstruksi pengetahuan yang dimiliki dan mengembangakan kemampuan HOT siswa.

Hasil analisis karakteristik siswa menunjukkan bahwa siswa SD masih berada pada tahap operasional konkret dengan usia 11 tahun. Anak-anak pada usia 7-11 tahun sudah cukup matang untuk berpikir menggunakan logika dan operasi namun hanya untuk benda atau objek yang nyata atau konkret (Sumantri 2014). Pembelajaran di SD hendaknya 
I Dewa Gede Putra Widiarta, Desak Putu Parmiti, dan I Gede Margunayasa

PENGEMBANGAN PERANGKAT PEMBELAJARAN INKUIRI TERBIMBING BERBASIS ... REFLEKSI EDUKATIKA : Jurnal Ilmiah Kependidikan 10 (1) Desember 2019. Hlm. 29-39

dilaksanakan dengan memberikan contoh-contoh yang nyata atau konkret dan memberikan bimbingan kepada siswa untuk mengkonstruksi pengetahuan yang dimiliki serta mengembangkan kemampuan HOT siswa dengan tepat. Hasil analisis digunakan sebagai acuan dalam merancang perangkat pembelajaran. Pada tahap design dilaksanakan perancangan perangkat pembelajaran berupa silabus, RPP dan LKPD dengan komponenkomponen yang berbeda pada masing-masing perangkat. Silabus meliputi komponenkomponen yang terdiri atas, 1) identitas sekolah, 2) kompetensi inti, 3) kompetensi dasar, 4) tema, 5) materi pokok, 6) pembelajaran, 7) penilaian, 8) alokasi waktu, 9) penilaian, dan 10) sumber belajar. Penyusunan RPP meliputi komponenkomponen yang terdiri atas, 1) identitas sekolah, 2) identitas mata pelajaran atau tema/subtema, 3) kelas/semester, 4) materi pokok, 5) alokasi waktu, 6) tujuan pembelajaran, 7) kompetensi dasar dan indikator pencapaian kompetensi, 8) materi pembelajaran, 9) metode pembelajaran, 10) media pembelajaran, 11) sumber belajar, 12 langkah-langkah pembelajaran, dan 13) penilaian hasil belajar. Penyusunan LKPD meliputi komponen-komponen yang terdiri atas, 1) sampul LKPD, 2) tujuan, 3) petunjuk kerja, 4) kegiatan siswa, dan 5) kesimpulan.

Pada tahap development perangkat yang telah dirancang kemudian dikembangkan komponen-komponennya mengikuti langkahlangkah pembelajaran inkuiri terbimbing berbasi aktivitas HOT. Perangkat pembelajaran dikembangkan sesuai dengan rancangan yang telah dibuat. Setelah perangkat pembelajaran selesai dikembangkan, dilaksanakan penilaian oleh empat ahli pembelajaran yang terdiri atas dua orang guru dan dua orang dosen dengan memberikan lembar penilaian perangkat pembelajaran.

Setelah perangkat selesai dikembangkan, perangkat kemudian di-review oleh ahli. Hasil review dari ahli kemudian dievaluasi untuk mengetahui validitas perangkat pembelajaran dengan menganalisis hasil validasi perangkat pembelajaran berupa skor oleh ahli. Berdasarkan analisis data yang dilaksanakan diperoleh ratarata skor validasi silabus yaitu 4,73, apabila dikonversikan dengan pedoman konversi skala lima berada pada rentang skor $4,01<X \leq 5,01$ dengan kualifikasi "sangat baik".

Berdasarkan hasil analisis data RPP yang dilaksanakan, menunjukkan bahwa masingmasing komponen pada RPP sebagian besar mendapatkan rata-rata skor validasi pada rentang skor $4,01<\mathrm{X} \leq 5,01$ dengan kualifikasi sangat baik, akan tetapi Komponen 7 pada RPP 3 mendapatkan rata-rata skor validasi pada rentang skor $3,33<X \leq 4,01$ dengan kualifikasi baik, karena pada Komponen 7 pada RPP 3 kompetensi dasar belum sesuai dengan silabus sehingga perlu dilaksanakan revisi terhadap komponen tersebut. Revisi dilaksanakan dengan menambahkan KD 1 dan KD 2 dan indikator pada muatan PPKn di RPP karena untuk muatan RPP KD 1 dan KD 2 dicantumkan pada silabus. Revisi juga dilaksanakan pada komponen tujuan pembelajaran pada RPP 5 karena belum memenuhi unsur ABCD. Tujuan pembelajaran seharusnya memenuhi asas ABCD yaitu audience, behavior, condition, dan degree (Sukri, et al., 2017). Rata-rata skor validasi RPP yaitu 4,75, apabila dikorversikan dengan pedoman konversi skala lima berada pada rentang skor $4,01<\mathrm{X} \leq 5,01$ dengan kualifikasi "sangat baik".

Berdasarkan analisis data LKPD yang dilaksanakan, menunjukkan bahwa masingmasing komponen pada LKPD sebagian besar mendapatkan rata-rata skor validasi pada rentang skor $4,01<X \leq 5,01$ dengan kualifikasi sangat baik, akan tetapi Komponen 3 pada semua LKPD mendapatkan rata-rata skor validasi pada rentang skor $3,33<\mathrm{X} \leq 4,01$ dengan kualifikasi baik, karena pada Komponen 3 pada semua LKPD tujuan belum sesuai dengan RPP dan belum menunjukkan HOT sehingga perlu dilaksanakan revisi terhadap komponen tersebut. Revisi dilaksanakan dengan memperbaiki tujuan LKPD disesuaikan dengan tujuan yang dicantumkan pada RPP sehingga menunjuukan HOT. Ratarata skor validasi LKPD yaitu 4,86, apabila dikorversikan dengan pedoman konversi skala lima berada pada rentang skor $4,01<\mathrm{X} \leq 5,01$ dengan kualifikasi "sangat baik". Perolehan hasil validitas perangkat (silabus, RPP, dan LKPD) berada pada kualifikasi yang positif (melebihi kategori baik) menunjukkan bahwa perangkat pembelajaran inkuiri terbimbing berbasis aktivitas HOT memiliki kualifikasi yang memadai (Pariatna, Sudria, dan Wasono, 2015).

Hasil analisis sejalan dengan temuan Nugraha, Ibrahim, dan Supardi (2015), yaitu perangkat pembelajaran IPA berdasarkan model inkuiri terbimbing layak untuk digunakan dalam pembelajaran. Penelitian ini juga sejalan dengan penelitian Uswatun dan Rohaeti (2015) yaitu perangkat pembelajaran IPA berbasis inkuiri layak untuk digunakan dalam pembelajaran dan mampu meningkatkan kemampuan berpikir kritis siswa. Penelitian Novia, Hufri, dan Dwiridal 
I Dewa Gede Putra Widiarta, Desak Putu Parmiti, dan I Gede Margunayasa

PENGEMBANGAN PERANGKAT PEMBELAJARAN INKUIRI TERBIMBING BERBASIS ...

REFLEKSI EDUKATIKA : Jurnal Ilmiah Kependidikan 10 (1) Desember 2019. Hlm. 29-39

(2017) mendapatkan hasil yang sejalan yaitu LKPD berorientasi inkuiri terbimbing valid, praktis, dan efektif digunakan dalam pembelajaran. Berdasarkan uraian tersebut perangkat pembelajaran inkuri terbimbing berbasis aktivitas HOT memiliki kualifikasi sangat baik sehingga layak untuk digunakan dalam pembelajaran.

Penelitian ini menghasilkan perangkat pembelajaran yang bisa digunakan oleh guru untuk meningkatkan aktivitas dan kemampuan HOT siswa. Perangkat pembelajaran inkuiri terbimbing berbasis aktivitas HOT berbeda dengan perangkat pembelajaran yang lain, karena kegiatan pembelajaran dalam perangkat pembelajaran ini dirancang dengan mengikuti sintaks inkuiri terbimbing yang mengarahkan siswa untuk memecahkan masalah secara mandiri. Pembelajaran dengan menggunakan perangkat pembelajaran inkuiri terbimbing berbasis aktivitas HOT mampu melibatkan siswa untuk aktif dalam kegiatan pembelajaran sehingga mampu melatih kemampuan HOT siswa. Pembelajaran dengan model inkuiri terbimbing melibatkan siswa untuk aktif, kreatif, dan inovatif membentuk karakter siswa menjadi lebih baik (Nugraha, Ibrahim, dan Supardi 2015). Perangkat pembelajaran berbasis inkuiri mampu meningkatkan keterampilan berpikir kritis dan sikap ilmiah siswa (Uswatun dan Rohaeti, 2015).

Kelebihan perangkat pembelajaran inkuiri terbimbing berbasis aktivitas HOT yaitu (1) perangkat pembelajaran ini telah sesuai dengan kurikulum 2013 dan pembelajaran Abad 21, (2) memberikan kemudahan bagi siswa untuk melakukan kegiatan pembelajaran, dengan adanya LKPD yang selaras dengan RPP, (3) membantu guru dalam melaksanakan proses pembelajaran karena kegiatan pada RPP disusun secara sistematis dan dibantu dengan LKPD, (4) Perangkat pembelajaran ini dapat meningkatkan kemampuan HOT siswa, (5) dapat meningkatkan keterampilan proses sains siswa, (6) memberikan pengalaman kepada siswa untuk membangun pengetahuannya melalui kegiatan yang dilakukan. Kekurangan dari perangkat pembelajaran inkuiri terbimbing berbasis aktivitas HOT yaitu belum diujicobakan secara langsung di sekolah.

\section{SIMPULAN}

Berdasarkan hasil penelitian dan pembahasan, dapat disimpulkan bahwa perangkat pembelajaran inkuiri terbimbing berbasis aktivitas HOT pada Tema 9 Subtema 1 kelas V SD yang terdiri atas silabus, RPP, dan
LKPD dinyatakan memiliki kualifikasi sangat baik. Hasil analisis data menunjukkan bahwa: (1) rata-rata skor validasi silabus yaitu 4,73, berada pada kualifikasi sangat baik, rata-rata skor validasi RPP yaitu 4,75, berada pada kualifikasi sangat baik, rata-rata skor validasi LKPD yaitu 4,86 , berada pada kualifikasi sangat baik, dan (2) Perolehan hasil validitas perangkat (silabus, RPP, dan LKPD) menunjukkan bahwa perangkat yang telah dikembangkan memiliki kualifikasi sangat baik.

\section{DAFTAR PUSTAKA}

Anugraheni, I. 2018. Pengembangan Perangkat Pembelajaran Matematika berbasis Pendidikan Karakter Kreatif di Sekolah Dasar. Refleksi Edukatika: Jurnal Ilmiah Kependidikan, 8 (2): 133-138.

Fathurrohman, M. 2015. Model-model Pembelajaran Inovatif: Alternatif Desain Pembelajaran yang Menyenangkan. Yogyakarta: Al-Ruzz Media.

Gunada, I W., Sahidu, H., dan Sutrio. 2015. Pengembangan Perangkat Pembelajaran Fisika Berbasis Masalah untuk Meningkatkan Hasil Belajar dan Sikap Ilmiah Mahasiswa. Jurnal Pendidikan Fisika Dan Teknologi, 1(1): 38-46.

Hananta, R. O., dan Sukardi, T. 2018. Pengembangan Model Media Video pada Pembelajaran Praktik Pemesinan Bubut. Jurnal Dinamika Vokasional Teknik Mesin, 3 (2): 121-129.

Ilias, K., \& Ladin, C. A. 2018. Pengetahuan dan Kesediaan Revolusi Industri 4.0 Dalam Kalangan Pelajar Institut Pendidikan Guru Kampus IPOH. O-JIE: Online Journal of Islamic Education, 6 (2): 18-26.

Istikharah, R., dan Zulkifli, S. 2017. Pengembangan Lembar Kegiatan Peserta Didik (LKPD) Kelas X SMA/MA pada Materi Pokok Protista berbasis Pendekatan Ilmiah. Jurnal Pendidikan Matematika dan Sains, 12 (1): 32-38.

Kemendikbud. 2016. Salinan Lampiran Permendikbud No. 22 Tahun 2016 Tentang Standar Proses Pendidikan 
I Dewa Gede Putra Widiarta, Desak Putu Parmiti, dan I Gede Margunayasa

PENGEMBANGAN PERANGKAT PEMBELAJARAN INKUIRI TERBIMBING BERBASIS ...

REFLEKSI EDUKATIKA : Jurnal Ilmiah Kependidikan 10 (1) Desember 2019. Hlm. 29-39

Dasar dan Menengah. Jakarta: Kemendikbud.

Khamdun. 2014. Peningkatan Hasil Belajar IPA Melalui Inkuiri Terbimbing pada Siswa SDN 1 Ngembalrejo Bae Kudus. Refleksi Edukatika: Jurnal Ilmiah Kependidikan, 4 (2).

Kizilaslan, A., Sozbilir, M., dan Yasar, M. D. 2012. Inquiry Based Teaching in Turkey: A Content Analysis of Research Reports. International Journal of Environmental \& Science Education, 7 (4): 599-617.

Lailly, N. R., \& Wisudawati, A. W. 2015. Analisis Soal Tipe Higherer Order Thinking Skill (HOTS) dalam Soal UN Kimia SMA Rayon B Tahun 2012/2013. Jurnal Kaunia, 11(1): 27-39.

Margunayasa, I G., et al. 2019. The Effect of Guided Inquiry Learning and Cognitive Style on Science Learning Achievement. International Journal of Instruction, 12 (1): 738-750.

Nugraha, A. W., Ibrahim, M., dan Supardi, I. 2015. Pengembangan Perangkat Pembelajaran IPA Berdasarkan Model Inkuiri Terbimbing untuk Melatihkan Penguasaan Konsep dan Keterampilan Berpikir Kritis Siswa SD. Jurnal Review Pendidikan Dasar: Jurnal Kajian Pendidikan dan Hasil Penelitian, 1 (1): 57-64.

Novia, R., Hufri, dan Dwiridal, L. 2017. Pengembangan LKPD berorientasi Inkuiri Terbimbing pada Materi Momentum, Impuls, dan Tumbukan untuk Siswa SMA/MA Kelas X. Pillar of Physics Education, 10 (1): 97-104.

Pariatna, I W. J., Sudria, I. B. N., \& Wasono, N. K. 2015. Pengembangan Perangkat Pembelajaran Inkuiri Terbimbing pada Topik Laju Reaksi. Wahana Matematika dan Sains: Jurnal Matematika, Sains, dan Pembelajarannya, 9 (1): 38-50.

Ramli, M. 2015. Implementasi Riset dalam Pengembangan Higher Order Thinking Skills pada Pendekatan Sains. Makalah disajikan dalam Seminar Pendidikan Sains V, Surakarta, 19 November 2015.

Retno, R. S., dan Marlina, D. 2018. Implementasi SETS (Science, Environment, Technology, Social) Terhadap Literasi Sains Siswa SDN 02 Mojorejo Madiun. Refleksi Edukatika: Jurnal Ilmiah Kependidikan, 9 (1): 33-39.

Rofiah, E., Aminah, N. S., dan Ekawati, E. Y. 2013. Penyusunan Instrumen Tes Kemampuan Berpikir Tingkat Tinggi Fisika pada Siswa SMP. Jurnal Pendidikan Fisika, 1 (2): 17-22.

Santosa, A. S. E., Santyadiputra, G. S., dan Divayana, D. G. H. 2017. Pengembangan E-modul berbasis Pembelajaran Problem Based Learning pada Mata Pelajaran Administrasi Jaringan Kelas XII Teknik Komputer dan Jaringan di SMK TI Bali Global Singaraja. Kumpulan Artikel Mahasiswa Pendidikan Teknik Informatika, 6 (1).

Sanjaya, W. 2016. Strategi Pembelajaran Berorientasi Standar Proses Pendidikan. Jakarta: Paramedia Grup.

Sari, K. A. D. R., Wiyasa, K. N., dan Ganing, N. N. 2018. Pengaruh Model Pembelajaran Inkuiri Terbimbing Berbantuan Media Konkret Terhadap Kompetensi Pengetahuan IPA. Jurnal Mimbar Ilmu, 23 (2): 104-112.

Simbolon, D. H., dan Sahyar. 2015. Pengaruh Model Pembelajaran Inkuiri Terbimbing berbasis Eksperimen Riil dan Laboratorium Virtual Terhadap Hasil Belajar Fisika Siswa. Jurnal Pendidikan dan Kebudayaan, 21 (3): 299-315.

Sukri, A., et al. 2017. Uji Validasi Bahan Ajar Berbasis Keunggulan Lokal di SDN Gili Matra, Lombok Utara Nusa Tenggara Barat. Jurnal Edukasi Matematika dan Sains, 5 (2): 92-97.

Sumantri, M. 2014. Modul Perkembangan dan Perkembangan Anak. Tersedia pada http://respository.ut.ac.id/4032/2/MKDK4 002-TM.pdf (diunduh tanggal $25 \mathrm{Mei}$ 2019). 
I Dewa Gede Putra Widiarta, Desak Putu Parmiti, dan I Gede Margunayasa

PENGEMBANGAN PERANGKAT PEMBELAJARAN INKUIRI TERBIMBING BERBASIS ...

REFLEKSI EDUKATIKA : Jurnal Ilmiah Kependidikan 10 (1) Desember 2019. Hlm. 29-39

Tanjung, H. S., dan Nababan, S. A. 2018. Pengembangan Perangkat Pembelajaran Matematika Berorientasi Model Pembelajaran Berbasis Masalah (PBM) untuk Meningkatkan Kemampuan Berpikir Kritis Siswa SMA Se-Kuala Nagan Raya Aceh. Genta Mulia: Jurnal Ilmiah Pendidikan, 9 (2): 56-70.

Uswatun, D. A., dan Rohaeti, E. 2015. Perangkat Pembelajaran IPA berbasis Inkuiri untuk Meningkatkan Critical Thinking Skills dan Scientific Attitude Siswa. Jurnal Inovasi Pendidikan IPA, 1 (2): 138-152.
Wahyuni, S. 2017. Development Test System Based On Linear Equations Two Variable Revised Taxonomy Bloom To Measure High Order Thinking Skills At Student Class VIII SMPN Sungguminasa Gowa. Jurnal Daya Matematis, 5 (1): 129-152.

Widodo, T., dan Kadarwati, S. 2013. Higher Order Thinking berbasis Pemecahan Masalah untuk Meningkatkan Hasil Belajar berorientasi Pembentukan Karakter Siswa. Jurnal Cakrawala Pendidikan, 5 (1). 